\title{
THE EFFECT OF ORGANIZATIONAL JUSTICE ON TURNOVER INTENTIONS: \\ A FIELD STUDY IN GAZIANTEP
}

\author{
Hüseyin ASLAN1, Mustafa Uçar2 \\ 1.Phd.Student at Department of Bussiness Administration of \\ Hasan Kalyoncu University. \\ 2. Professor Dr. at Department of Bussiness Administration of \\ Hasan Kalyoncu University.
}

\section{Abstract}

The aim of this study is to determine employee perception of organizational justice which is an indicative of employee turnover intentions. In accordance with this purpose, 150 questionnaires were conducted with the employees of 3-4 and 5 star hotels still operating in Gaziantep.

Analyses show that, there is a significant and negative correlation between organizational justice and employee turnover intentions. Results indicate that factors of organizational justice reduce the rate of employees' turnover intentions.

Key Words: Organizational justice, turnover intentions.

\section{Council for Innovative Research}

Peer Review Research Publishing System

Journal: Journal of Social Sciences Research

Vol. 9, No. 3

editor@jssronline.com

www.jssronline.com 


\section{INTRODUCTION}

The increase in the number of studies regarding the concept of organizational justice proves the importance of the subject. One of the factors which organizational justice has an effect on is turnover intentions of employees.

As long as employees complete each other's inadequacies and cover the needs of one another, their interaction in organization survives. The way individuals behave during these interactions, depends on the people they look up to (Kulik \& Ambrose, 1992:212). According to Adams (1965), employees always compare their investments (educational background, experience, performance etc.) and gains (wage, promotions, equality, recognition etc) with the people who are in the same status as them. Employees do this comparison based on their own standards of justice. Individual's perception of justice differs from each other. Therefore, these different perceptions result in positive of negative behaviors. The positive perception of organizational justice increases the organizational commitment and productivity. The negative perception of organizational justice, on the other hand, harms the organization and employee turnover rates escalate.

Organizational justice is considered to be one of the leading factors affecting the intentions of employees to quit and helping them to work in a secure workplace environment. In this context, attitudes and behaviors towards employees is of great importance since the concepts of justice, trust, satisfaction and belongingness are the key factors of success in organizations (Demirkaya and Kandermir, 2014:15)

This study aims to measure the effect of employees' sense of organizational justice on their turnover intentions. This study is based on the data analyses collected from the hotel employees in the scope of necessary requirements. The findings are expected to contribute to the literature.

\section{LITERATURE REVIEW}

When we examine the literature, we see that in order to explain employee turnover intentions, a lot traditional models mostly focus on the behaviors of employees against their jobs and organizations (Farrell and Rusbult, 1981;Mobley, 1977; Steers and Mowday, 1981). These models indicate that considering leaving the job as an option complies with the premise of low level of organizational commitment and satisfaction.

The factors affecting the employee turnover intentions can be categorized as external factors (unemployment rate, alternative job opportunities etc.), organizational factors (wages, rewarding, management type etc) and personal factors (personality, age, family backgroundetc.) (Cotton and Tuttle, 1986; 63-64). Employees take these factors into consideration so as to decide on their level of job satisfaction. If an employee is dissatisfied with his job, then he looks for the possibilities of quitting his job and of new employment opportunities. Then the employee comes to a decision by making a comparison between his current job and the other job opportunities (Mobley, 1977; 238). The existence of justice in an organization is the indication of the commitment to its employees. In this case, employees would also be loyal to the organization (Fischer, 2004). Employees exhibit intentions to leave their job in the case of feeling treated unfairly by their organization (Gürpınar, 2006:56).

In the studies of Alexander and Ruderman(1987), Konovsky and Cropanzano(1991),Lipponnen et al. (2004) the results show that employees who think they are unfairly paid, have a high tendency to quit their jobs.

According to the studies of Çakar and Ceylan (2005:60), the more the employees' commitment to their organization, the less they show the indications of turnover intentions.

In the study of Dailey and Kirk (1992:305), it is stated that the most influential factor in employee turnover intentions is the perception of operational justice. Alexander and Ruderman (1987:177) reported that the reason for turnover intentions is related directly to employees' sense of distributive justice.

Altıntaş (2006:31), however, states in his study in which he conducted a research on the academicians with different titles in various state universities in Turkey that distributive justice has no effect whatsoever on turnover intentions.

In the Meta analysis study of Colquitt et al. (2001) regarding the outcomes of organizational justice, both distributive and procedural justice are stated to have a high rate of negative correlation with employee turnover intention.

In the study by Özer and Günlük (2010), a high rate of negative correlation between organizational justice and turnover intentions was determined.

In the study of Örücü ve Özafşaroğlu(2013), it is stated that there is a negative and a significant correlation between employees' perceptions of organizational justice and their intentions to quit job.

\section{METHODOLOGY}

\subsection{Subject}

This study aims to find the effect of distributional, procedural and interactional justice in businesses on employees working in hotel managements in Gaziantep. In this research, opinions of employees working in hotels in Gaziantep about justice and turnover intentions were analyzed. 


\subsection{Objective and Importance}

The effect of justice on employee commitment in hotel managements is a very important issue. It isthought that the perception of employees regarding justice affects employees' turnover intentions.

One of the most important sectors in Turkey is tourism. And the most important business in tourism sector is hotel managements. In this study, we aim to determine the effect of employees' perception of justice on their turnover intentions in hotel managements in Gaziantep.

\subsection{The Population and the Sample}

The sample of this study involves 750 people from 3-4 and 5 star hotels in Gaziantep. It was intended to reach the target number of participants, yet some employees could not be reached. Therefore, 170 people were able to fill in the questionnaires. However, 20 questionnaires seemed to be corrupted or incomplete, so only 150 questionnaires were analyzed.

In the studies regarding the proper sample number to represent the population, acceptable number of sample was stated to be 140. In other words, sample of this study has the characteristics of representing the population.

\subsection{Data Collection Tools}

In this research, questionnaires were used as data collection tools. Questionnaires consist of two parts and 35 questions in total. In the first part, there are questions about demographical information about participants, and in the second part there are 25 questions regarding the perceptions about distributive, procedural and interactional justice and turnover intentions. The second part of the questionnaire was prepared with the help of the adapted version of organizational justice scale developed by Niehoff and Moorman (1993). Questions about turnover intentions were adapted from Reychav and Weisberg (2009). In this part, 5 point likert scale was used and the items were " $1=$ Strongly disagree....5= Strongly agree". As a data analysis tool, SPSS 21.0 package program was used and this research was done in October 2015 by researchers themselves.

\subsection{Hypotheses}

In order to test the relations in line with the purpose of the study, following hypotheses were made:

$\mathrm{H}_{1}$ : There is a significant correlation between the employee turnover intentions and the perception of interactional justice in hotel managements.

$\mathrm{H}_{2}$ :There is a significant correlation between the employee turnover intentions and the perception of procedural justice in hotel managements.

$\mathrm{H}_{3}$ : There is a significant correlation between the employee turnover intentions and the perception of distributive justice in hotel managements.

\subsection{Results and Discussion}

This part consists of three sections. In the first section, demographical information of participants, in the second section validity and reliability analyses and in the third section correlation and regression analyses are given.

\subsubsection{Demographical Information of Participants}

Tables regarding participants' age, sex, educational background, tourism education, the unit they work in, working time, monthly income are shown below.

Table 1. Participants by their sex

\begin{tabular}{llcc}
\hline & & N & Percentage (\%) \\
\hline \multirow{3}{*}{ Sex } & Male & 116 & 77,3 \\
& Female & 34 & 22,7 \\
& Total & $\mathbf{1 5 0}$ & $\mathbf{1 0 0 . 0}$ \\
\hline
\end{tabular}

In table 1, the distribution of participants by their sex is demonstrated. According to the table, $116(77,3 \%)$ participants are male and $34(22,7 \%)$ of them are female. 
Table 2. Participants by their age group

\begin{tabular}{llcc}
\hline & N & Percentage (\%) \\
\hline \multirow{4}{*}{ Age } & $18-30$ & 55 & 36.7 \\
& $31-40$ & 73 & 48.7 \\
& $41-50$ & 20 & 13.3 \\
& 51 and above & 2 & 1.3 \\
& Total & $\mathbf{1 5 0}$ & $\mathbf{1 0 0 . 0}$
\end{tabular}

Distribution of participants by their age group is shown in Table 2 According to this table, most of the participants are between 31 and 40 ( $n=73$ ). Additionally, there are 15 participants from 18-30 age group, 20 participants from $42-50$ age group, and 2 people from 51 and above age group.

Table 3. Participants by their educational backgrounds

\begin{tabular}{llcl}
\hline & & $\mathrm{N}$ & Percentage $(\%)$ \\
\hline & Primary School & 43 & 28.7 \\
& High School & 94 & 62.7 \\
Educational & Associate degree & 10 & 6.7 \\
& Undergraduate & 3 & 2.0 \\
& Total & $\mathbf{1 5 0}$ & $\mathbf{1 0 0 . 0}$
\end{tabular}

Participants' educationalbackground is shown in Table 3 According to the table, out of 150 participants, 43 (28,7 \%) people are primary school graduates, $94(62,7 \%)$ of them are high school graduates, $10(6,7 \%)$ of them got associate degree and $3(2,0 \%)$ of them are undergraduates.

Tablo 4. Participants' tourism education background

\begin{tabular}{llcc}
\hline & & $\mathrm{N}$ & Percentage (\%) \\
\hline \multirow{2}{*}{ Tourism } & Yes & 20 & 13,3 \\
Education & No & 130 & 86,7 \\
& Total & $\mathbf{1 5 0}$ & $\mathbf{1 0 0 . 0}$
\end{tabular}

Table 4 shows the distribution of participants by their tourism education ('Did you take any tourism and hotel management training?"). 20 participants (13.3\%) said yes and 130 participants $(86,7 \%)$ said no.

Table 5. Participants' positions in business.

\begin{tabular}{llcl}
\hline & $\mathrm{N}$ & Percentage (\%) \\
\hline \multirow{4}{*}{ Position } & Senior Manager & 43 & 28.7 \\
& Mid-level Manager & 94 & 62.7 \\
& Junior Administrative Officer & 10 & 6.7 \\
& Other Hotel Employees & 3 & 2.0 \\
& Total & $\mathbf{1 5 0}$ & $\mathbf{1 0 0 . 0}$ \\
\hline
\end{tabular}

Table 5 shows the distribution of participants by their position in banks. According to the table, 1 person $(0,7 \%)$ is a senior manager, $10(6,7 \%)$ participants are mid-level manager and $20(13,3 \%)$ participants are junior administrative officer. Also, $119(79,3 \%)$ of participants are other hotel employees. 
Table 6. Participants by the units they work in

\begin{tabular}{llll}
\hline & $\mathrm{N}$ & Percentage (\%) \\
\hline Accounting & 3 & 2.0 \\
Front office & 37 & 24.7 \\
Snits & 11 & 7.3 \\
& Foles marketing & 73 & 43.7 \\
& Technical service & 2 & 1.3 \\
& Housekeeping & 24 & 16.0
\end{tabular}

Table 6 shows the distribution of participants in terms of the units they work in. We can see in the table that 3 participants are $(2.0 \%)$ in accounting, $37(24,7 \%)$ participants are in front office, $11(7,3 \%)$ participants are in sales marketing, 73 $(43,7 \%)$ participants are in food and beverage, $2(1,3 \%)$ of them are in housekeeping department.

Table 7. Participants' distribution by their working time in the sector

\begin{tabular}{llll}
\hline & & $\mathrm{N}$ & Percentage (\%) \\
\hline \multirow{2}{*}{ Less than 1 year } & 1 & 0.7 \\
& $1-3$ years & 25 & 16.7 \\
& $4-6$ years & 67 & 44.7 \\
& $7-9$ years & 35 & 23.3 \\
& 10 years and more & 22 & 14.7 \\
& Total & $\mathbf{1 5 0}$ & $\mathbf{1 0 0 . 0}$
\end{tabular}

According to Table 7, which shows the distribution of participants by their working time in the sector, $1(0,7 \%)$ participant works less than one year, 25 (16,7\%) participants work between 1-3 years, 67 (44,4\%) participants work between 4-6 years, $35(23,3 \%)$ participants work between 7 to 9 years and $22(1,3 \%)$ participants work 10 years and more in the sector.

Table 8. Distribution of participants by their monthly income

\begin{tabular}{llcc}
\hline & $\mathrm{N}$ & Percentage (\%) \\
\hline & $800 \mathrm{TL}$ and less & 1 & 0.7 \\
$801-1000 \mathrm{TL}$ & 65 & 43.3 \\
Income & $1001-2000 \mathrm{TL}$ & 74 & 49.3 \\
& $2001-3000 \mathrm{TL}$ & 7 & 4.7 \\
& $3001-4000 \mathrm{TL}$ & 3 & 2.0 \\
& Total & $\mathbf{1 5 0}$ & $\mathbf{1 0 0 . 0}$ \\
\hline
\end{tabular}

Table 8 shows the distribution of participants by their monthly income. According to the table, $1(0,7 \%)$ person has $800 \mathrm{TL}$ and less, 65(43,3\%) participants have 801-1000 TL, $74(49,3 \%)$ participants have 1001-2000 TL, 7 (4,7\%) participants have between 2001 and 3000 TL, 3 (2,0\%) people have 3001-4000 TL monthly income.

\subsubsection{Results of Reliability Analysis}

Second part of the results section deals with the reliability analysis results. Table 9 shows the results of analysis regarding the questions about turnover intentions and distributive, procedural and interactional justice. 
Table 9. Results of reliability analysis

\begin{tabular}{|l|l|l|}
\hline Faktors & Cronbach's Alpha & N of Items \\
\hline Distributive Justice & 0,972 & 5 \\
\hline Interactional Justice & 0,916 & 6 \\
\hline Procedural Justice & 0,980 & 9 \\
\hline \multicolumn{1}{|c|}{ Turnover Intention } & 0,995 & 5 \\
\hline
\end{tabular}

Cronbach's Alpha was examined for the reliability analysis of question items. Whether the statements are consistent or not is understood by measuring the relationship among them. In this way, we get reliability coefficient, which takes a value between 0 and 1 and the reliability increases when the value gets close to 1 (Ural ve Kılıç, 2005:258). Cronbach Alpha values of the factors are calculated as; $0.972,0.916,0.980$ and 0.995 relatively. According to Turan (2012:8), "If the Cronbach's Alpha value is above 0,70 , then the scale is reliable." Therefore, the scale is reliable as we can see.

\subsubsection{Results of Correlation and Regression Analysis}

The purpose of our study is to examine the effect of distributional, procedural and interactional justice on turnover intentions. In this context, the outline of the study is given in the template below.

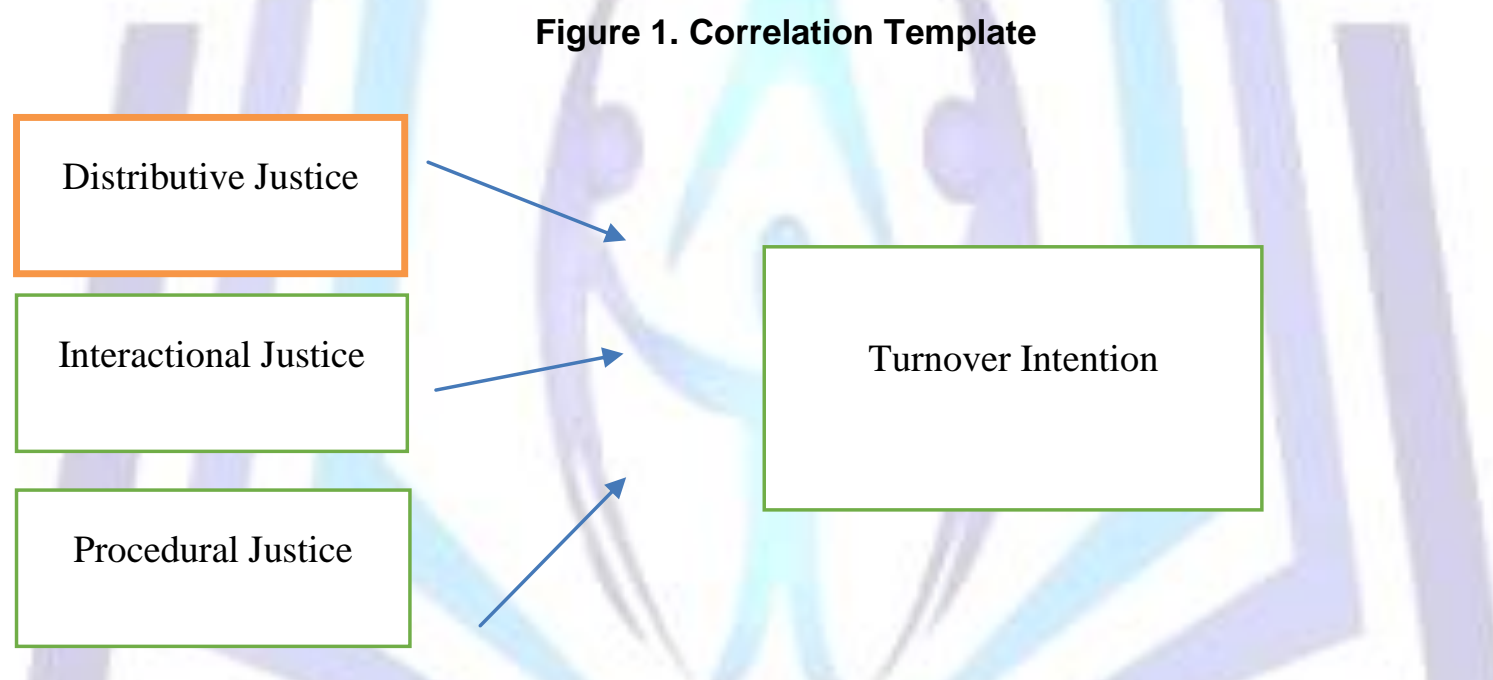

Correlation test is used to determine the intensity and the direction of the relationship between two variables. (Ural and Kılıç, 2013:243). In this study, correlation test was used in order to determine the relationships between "Distributive Justice" and "Turnover Intention", "Interactional Justice" and "Turnover Intention", "Procedural Justice" and "Turnover Intention".

As it can be seen in Table 10, there is a negative and moderate correlation between turnover intentions and interactional justice (Pearson Correlation coefficient $=-, 416$ ).

Table 10. Correlation Results of Turnover Intention and Interactional Justice

\begin{tabular}{|c|c|c|c|}
\hline \multicolumn{4}{|l|}{ Correlations } \\
\hline & & Turnover Intention & Interactional Justice \\
\hline \multirow{3}{*}{ Turnover Intention } & Pearson Correlation & 1 &,$- 416^{\star \star}$ \\
\hline & Sig. (2-tailed) & & ,000 \\
\hline & $\mathrm{N}$ & 150 & 150 \\
\hline \multirow{3}{*}{ Interactional Justice } & Pearson Correlation &,$- 416^{\star \star}$ & 1 \\
\hline & Sig. (2-tailed) & ,000 & \\
\hline & $\mathrm{N}$ & 150 & 150 \\
\hline
\end{tabular}


As a result of this correlation analysis, $\mathbf{H}_{1}$ : "There is a significant correlation between the employee turnover intentions and the perception of interactional justice in hotel managements." was accepted.

Table 11. Correlation Results of Turnover Intention and Procedural Justice

\begin{tabular}{|l|l|l|l|}
\hline Correlations & & Turnover Intention & Procedural Justice \\
\hline \multirow{4}{*}{ Turnover Intention } & Pearson Correlation & 1 &,$- 563^{\star *}$ \\
\cline { 2 - 4 } & Sig. (2-tailed) & & 0,00 \\
\cline { 2 - 4 } & $\mathrm{N}$ & 150 & 150 \\
\hline \multirow{3}{*}{ Procedural Justice } & Pearson Correlation &,$- 563^{\star \star}$ & 1 \\
\cline { 2 - 4 } & Sig. (2-tailed) & 0,00 & 150 \\
\cline { 2 - 4 } & $\mathrm{N}$ & 150 & \\
\hline
\end{tabular}

Table 11 shows that there is a negative and significant correlation between turnover intention and procedural justice. (Pearson Correlation coefficient $=-, 563$ )

As a result of this correlation analysis, $\mathrm{H}_{2}$ : "There is a significant correlation between the employee turnover intentions and the perception of procedural justice in hotel managements." was accepted.

Table 12. Correlation Results of Turnover Intention and Distributive Justice

\begin{tabular}{|c|c|c|c|}
\hline Correlations & & & \\
\hline & & Turnover Intention & Distributive Justice \\
\hline & Pearson Correlation & 1 &,$- 040^{\star \star}$ \\
\hline Turnover Intention & Sig. (2-tailed) & & ,626 \\
\hline & $\mathrm{N}$ & 150 & 150 \\
\hline & Pearson Correlation &,$- 040^{\star *}$ & 1 \\
\hline Distributive Justice & Sig. (2-tailed) & ,626 & \\
\hline & $\mathrm{N}$ & 150 & 150 \\
\hline
\end{tabular}

As Table 12 shows, there seems to be no correlation between turnover intention and distributive justice. In this case, $\mathrm{H}_{3}$ : "There is a significant correlation between the employee turnover intentions and the perception of distributive justice in hotel managements." was refused.

\section{Table 13. Results of Regression Analysis}

\begin{tabular}{|c|c|c|c|c|c|c|}
\hline Independent Variables & $\beta$ & $\mathrm{T}$ & $p$ & $\mathrm{R}^{2}$ & Adjusted $\mathrm{R}^{2}$ & $\mathrm{~F}$ \\
\hline Procedural Justice & ,815 & -13.204 & .000 & \multirow{2}{*}{.378} & \multirow{2}{*}{.368} & \multirow{2}{*}{44.583} \\
\hline Interactional Justice & $-1,420$ & .556 & .000 & & & \\
\hline
\end{tabular}

Regression analysis was made to determine the effect of interactional and procedural justice on turnover intentions.Results are shown above in the Table 13. It is found that there is a negative and significant effect of interactional and procedural justice on turnover intentions $(F=44.339 ; p<0.001)$. Adjusted $R^{2}$ is 0.368 and the perception of interactional and procedural justice explains the $36 \%$ ofturnover intentions.

\section{CONCLUSION}

We reached important results in this study which was done in order to determine the effects of organizational justice perceptions on turnover intentions. First of all, correlation was established among distributive, interactional and procedural justice and turnover intentions. As a result of the correlation analyses, it is seen that there is a correlation between interactional justice and turnover intentions, and between procedural justice and turnover intentions. The hypotheses in the beginning of the study;

$\mathrm{H}_{1}$ : There is a significant correlation between the employee turnover intentions and the perception of interactional justice in hotel managements. 


\section{ISSN 2321-1091}

$\mathrm{H}_{2}$ : There is a significant correlation between the employee turnover intentions and the perception of procedural justice in hotel managements.

were accepted.

There is no correlation between distributive justice and turnover intentions, on the other hand. Therefore the hypothesis;

$\mathrm{H}_{3}$ : There is a significant correlation between the employee turnover intentions and the perception of distributive justice in hotel managements.

was refused.

In the light of these findings, it has been determined that interactional and procedural justices in hotel managements have a negative and significant correlation with turnover intentions.

As a secondary analysis regression analyses were made. As a result of these analyses, it was determined that the perceptions of procedural and interactional justices have a negative and significant correlation with turnover intentions. ( $F$ $=44.339 ; p<0.001)$. The value of Adjusted $R^{2}$ is 0.368 , showing that the perceptions of interactional and procedural justice explains the $36 \%$ of turnover intentions.

As a consequence, we see that the perceptions of organizational justice in hotel managements have a positive effect on employee turnover intentions, meaning that these positive perceptions increase the organizational commitment and reduces the rate of turnover intentions.

\section{REFERENCE}

1. Akbulut,Y.(2010). Sosyal Bilimlerde SPSS Uygulamaları, İdeal Kültür Yayınları: İstanbul

2. Alexander, S., ve Ruderman, M. (1987). "The Role of ProceduralandDistributiveJustice in OrganizationalBehavior".SocialJusticeResearch, Vol. 1, No. 2 177-198.

3. Altıntaş, C. F. (2006). Bireysel Değerlerin Örgütsel Adalet ve Sonuçları İlişkisinde Yönlendirici Etkisi: Akademik Personel Üzerinde Bir Analiz. İşletme FakültesiDergisi, 7(2),19-40.

4. Altunışık,R.,Coşkun,R.,Bayraktaroğlu,S. ve Yıldııı,E.(2007). Sosyal Bilimlerde Araştırma Yöntemleri: SPSS Uygulamalı.(3. Baskı) İstanbul: Avcı Ofset

5. Altunışık,R.,Coşkun,R.,Bayraktaroğlu,S. ve Yıldırım,E.(2007). Sosyal Bilimlerde Araştırma Yöntemleri: SPSS Uygulamalı. (4. Baskı) İstanbul: Avcı Ofset.

6. Cihangiroğlu,N. ve Yılmaz,A.(2010). Çalışanların Örgütsel Adalet Algısının Örgütler için Önemi. Selçuk Üniversitesi Sosyal ve Ekonomik Araştırmalar Dergisi, 13 (19), ss.195-210.

7. Colquitt JA, Conlon DE, Wesson MJ, Porter COLH, Ng KY. (2001). "Justice At The Millennium: A MetaanalyticReview Of 25 Years Of OrganizationalJusticeResearch".Journal of ApplyPsychology, Vol. 86(3), s.42545.

8. Cotton, J.L. veTuttle, J.M. (1986). "EmployeeTurnover: A Meta-Analysis andReviewwithlmplicationsforResearch". The Academy of Management Review, 11(1), 55-70.

9. Çakar N. D. ve Ceylan A. (2005). "İş Motivasyonunun Çalışan Bağlılığı ve İşten Ayrılma Eğilimini Üzerindeki Etkileri”.Doğuş Üniversitesi Dergisi, 6 (1) ,52-66.

10. Daileyl, R.C. veKirk, D.J. (1992). "DistributiveandProceduralJustice As Antecedents Of JobDissatisfactionandintenttoTurnover". Human Relations, 45 (3), 305-317.

11. Demirkaya,H. ve Kandemir,H.(2014). Örgütsel Adaletin Boyutları ile Örgütsel Güven Arasındaki İlişkinin Analizine Yönelik Bir İşletme İncelemesi. Atatürk Üniversitesi Sosyal Bilimler Enstitüsü Dergisi.18 (2): 263-279

12. Farrell, D. ve Rusbult, G. E. (1981). "Exchange Variables As Predictors Of JobSatisfaction, JobCommitmentandTurnover: Theimpact of rewards, costs, alternatives, andinvestments". OrganizationalBehaviorand Human Performance, Vol. 28, p.78-95.

13. Fischer, R. (2004)."RewardingEmployeeLoyalty: An OrganizationalJusticeApproach". International Journal of OrganizationalBehavior, 8(3), 486-503.

14. Gürpınar,G.(2006). An EmpricalStudy of RelationshipsAmongOrganizationalJustice, OrganizationalCommitment, Leader-Member Exchange andTurnoverIntention. Yüksek Lisans Tezi, Yeditepe Üniversitesi, İstanbul.

15. Hom, P.W. ve Griffeth, R.W. (1995). EmployeeTurnover. Ohio: South-Western College.

16. Konovsky, M.A. ve Cropanzano, R. (1991). PerceivedFairness of EmployeeDrugTesting as a Predictor of EmployeeAttitudesandJobPerformance.Journal of AppliedPsychology, Vol. 76, No.5,698-707

17. Kulik, C. T. veAmbrose, M. L. (1992). PersonalandSituationalDeterminants Of ReferentChoice. Academy of Management Review, 17, 212-237.

18. Lipponen, J.,Olkkonen, M.E. ve Myyry, L., (2004). Personal Value Orientation as a Moderator in theRelationshipsBetweenPerceivedOrganizationalJusticeanditsHypothesizedConsequences.

SocialJusticeResearch, Vol.17, No. 3, 275-292.

19. Mobley, W. H.,Griffeth, R. W., Hand, H. H., ve Meglino, B. M., (1979), "ReviewandConceptual Analysis Of TheEmployeeTurnoverProcess".PsychologicalBulletin, 86, pp. 493-522

20. Mobley, $\quad$ W.H. (1977).
theRelationshipbetweenJobSatisfactionandEmployeeTurnover".Journal of AppliedPsychology, 62(2), 237-240. 
21. Niehoff, B.P.,\&Moorman, R. H. (1993). Justice As A Mediator Of TheRelationshipBetweenMethods of MonitoringandOrganizationalCitizenshipBehavior. Academy ofManagement Journal, 36(3), 527-556

22. Örücü,E. ve Ozafşaroglu,S.(2013). Örgütsel Adaletin Çalışanların İşten Ayrılma Niyetine Etkisi: Güney Afrika Cumhuriyetinde Bir Uygulama. Mustafa Kemal Üniversitesi Sosyal Bilimler Enstitüsü Dergisi Cilt:10,sayı:23. 335358

23. Özer,G.veGünlük,M(2010). Örgütsel Adaletin Muhasebecilerin İş Memnuniyeti ve İşten

24. Ayrılma Eğilimine Etkisi. Gaziantep Üniversitesi Sosyal Bilimler Dergisi. 9(2):459-485

25. REYCHAV, I. ve WEISBERG , J., 2007. "Impact Of Knowledge Sharing On PerformanceAndTurnover", The International Journal Of Knowledge CultureAndChange Management M. Kalantzis, B. Cope (Eds.) 6(2), ss.167176.

26. Steers, R.M., ve Mowday, R.T. (1981). EmployeeTurnoverandPostdecisionAccommodationProcesses. In L.L. Cummingsand B.M. Staw (eds.), Research in organizationalbehavior, 3, 235-281. Greenwich, Conn.: JAI Press.

27. Turan,i..(2012). Temel İstatistik Ders Notları

28. TUTAR H. (2007), "Erzurum' da Devlet ve Özel Hastanelerde Çalışan Sağlık Personelinin İşlem Adaleti, İş Tatmini ve Duygusal Bağlılık Durumlarının İncelenmesi”.Süleyman Demirel Üniversitesi iỉBFDergisi, Cilt: 12, Sayı:3, Isparta, s. 97 - 120

29. Ural, A. ve Kılıç, İ. (2005). Bilimsel araştırma süreci ve SPSS ile veri analizi. Detay Yayıncılık: Ankara

30. Yelboga,A.(2012).Örgütsel Adalet ile İş Doyum İlişkisi.Ege Akademik Bakış Dergisi.Cilt:2,Sayi:2. s.171-18

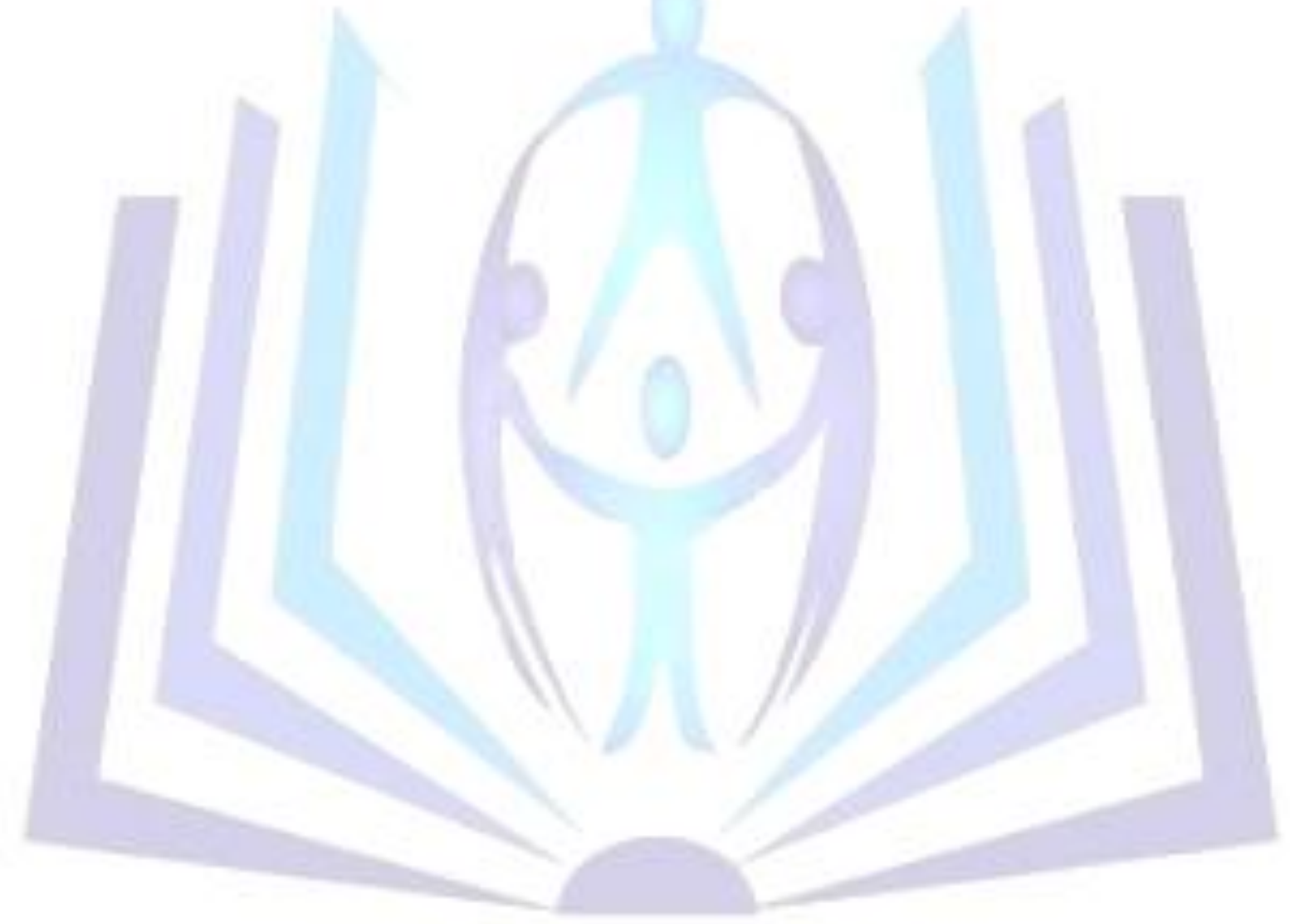

